\title{
浮屋根式円筒液体貯槽の地震時スロッシング応答の解析解 SLOSHING IN A CYLINDRICAL LIQUID-STORAGE TANK WITH FLOATING ROOF UNDER EARTHQUAKE EXCITATION : ANALYTICAL SOLUTION
}

\author{
松井徹哉* \\ Tetsuya MATSUI
}

\begin{abstract}
An analytical solution is presented to predict the sloshing response of a cylindrical liquid-storage tank with floating roof under earthquake excitation. The containing liquid is assumed to be invicid, incompressible and irrotational, while the floating roof be an isotropic elastic plate with uniform stiffness and mass. The dynamic interaction between the floating roof and the liquid is taken into account exactly within the framework of linear potential flow theory. By employing the Fourier-Bessel expansion technique in cylindrical coordinates the solution is derived in an explicit form, which is convenient for parametric understanding of the sloshing behavior and preliminary study in the early design stage. Numerical results are also provided to investigate the effect of the stiffness and mass of the floating roof on the sloshing response.
\end{abstract}

Keywords: liquid-storage tank, floating roof, sloshing, long-period earthquake motion, potential theory, analytical solution 液体貯槽, 浮屋根, スロッシング, 長周期地震動, ポテンシャル理論, 解析解

1. 序

液体貯槽の耐震設計を行う上で重要な検討要目の一つに内容 液のスロッシング (液面動摇) がある ${ }^{1)}$ 。過去の大地震ではス ロッシングに起因すると考えられる液体貯槽の被害が多発してい る。特に 1964 年の新鼬地震, 1983 年の日本海中部地震や 2003 年の十勝沖地震では, 浮屋根式石油眝槽に原油の溢流, 浮屋根 の損傷・沈没や火災などの甚大な被害が発生し関係者に衝撃を 与えるとともに，その原因の究明と再発防止策の検討が耐震工 学における重要課題の一つとして認識されるようになった。

自由液面のスロッシング応答に関しては, 線形ポテンシャル 理論解 ${ }^{2)}$ があり，スロッシング波高・周期や眝槽側壁に作用す る動液圧の算定式として設計指針等 ${ }^{3)} に も$ 広く採用されてい る。一方，浮屋根が存在する場合については，浮屋根が液面の 変位を拘束する効果を減衰定数のみに集約させ, 自由液面の算 定式を代用して波高や動液圧の推定を行っているのが現状であ り，浮屋根の効果や浮屋根に生じる応力を内部夜体との連成作 用を考慮して検討することは，通常の設計では行われていない。 従来, 浮屋根は付属物として取り扱われ強度検討の対象からは 除外されていたため, 設計時に浮屋根の挙動については十分に 検討されることはなく，このことが浮屋根式貯槽の被害を大き くしている一因とも考えられる。上記のような被害を防止し安
全な眝槽を設計するためには，浮屋根の挙動を弾性体と内部液 体との連成振動として捉え，浮屋根に生じる応力を正確に算定 し安全性を確珰するプロセスが是非とも必要である4)。

このような観点から浮屋根式液体貯槽のスロッシング挙動 を理論的に解明しようと試みた研究には，古くは Senda and Nakagawa ${ }^{2)}$ の研究や新鼬地震のタンク火災を契機として行わ れた山本 ${ }^{5)}$ の研究がある。これら初期の研究では浮屋根を質量 の無視し得る剛体板と仮定しポテンシャル理論を適用して内部 液体との連成振動問題を解いている。浮屋根を質量のある弾性 体として扱い液体との連成振動問題を解いたのは坂井ら ${ }^{6)}$ が 最初であり，境界積分型の変分原理を利用してリッツ法（有限 要素法）により解析する手法を提案し，浮屋根の存在が固有振 動性状に与える影響について詳細な解析と実験を行っている。 またこの手法を適用して半地下式石油備蓄タンクの浮屋根応力 の計算を行い 7 , 日本海中部地震や十勝沖地震に捣る浮屋根 被害の分析を試みている ${ }^{4)}$ 。一方最近では，汎用の有限要素解 析ソフトを利用して, 浮屋根と内部液体との連成振動を, 塑性 化, 大変形, 有限振幅波高などの構造・流体非線形効果をも含 めて詳細に解析することも行われている ${ }^{8)}$ 。このように現在で は, 浮屋根式液体眝槽のスロッシング応答を理論的に予測する ための解析ツールは十分に整えられている状況にはあるが、計

\footnotetext{
$*$ 名城大学理工学部建築学科 教授.工博 Prof., Dept. of Architecture, Faculty of Science and Technology, Meijo Univ., Dr. Eng.
} 
算に多大な労力を必要とする非線形詳細解析はスロッシング基 本性状のパラメトリックな把握や初期設計段階での予備的な検 討には必ずしも適さない。たとえ線形理論の範囲内であっても， 浮屋根と内部夜体との連成振動を解析的に表現した解があれば, 基本性状の把握や初期設計段階での検討に有用であると思われ るが，このような理論解を提示した研究は見当たらない。

本稿では, 一様な剛性・啠量分布の浮屋根を你する剛な平底 円筒液体泞槽を対象に, 地震時スロッシング応答の解析解を線 形ポテンシャル理論に基づき導出する。さらに, 解析例により 浮庄根の形式, 剛性や貎最がスロッシング応答に及ぼす影響を 検討する。

\section{2. 理論解の導出}

\section{1 境界値問題}

図 1 に示すような平底円简液体貯槽の地㕠时液|纨動摇䦌题を 扱う。眝槽は剛体であると仮定し，その半径を $R$, 液体の深さ

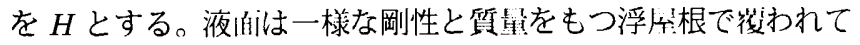

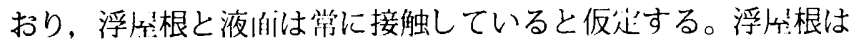

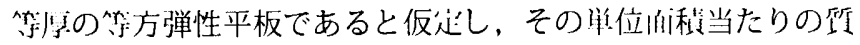
战を $m$ ，曲げ剛性を $D$ ，ポアソン比を $\nu$ とする。

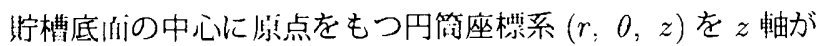
鉛田上向きになるようにとる。内容液は珄想流体で綜形ポテン シャル理論が成立すると仮运すると， $O=0$ の方向に水平地動 変位 $x_{g}(t)$ を受けた埸合の速庭ポテンシャル $\phi$ の境界㑬湖题は 次のように㲹述される。

$$
\begin{aligned}
& \nabla^{2} \phi=0 \quad \text { 流体领域で } \\
& \frac{\partial \phi}{\partial r}=\dot{x}_{g}(t) \cos \theta \quad \text { 側壁 } r=R \text { で } \\
& \frac{\partial \phi}{\partial z}=0 \quad \text { 底治 } z=0 \text { で }
\end{aligned}
$$

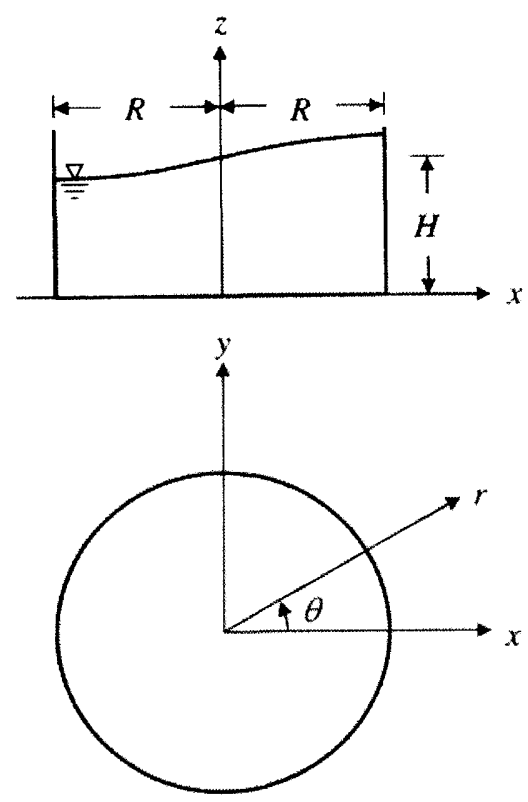

図 1: 貯槽の形状と座標系

$$
\frac{\partial \phi}{\partial z}=\dot{w}(t) \quad \text { 液面 } z=H \text { で }
$$

ここに, $w(t)$ は浮屋根の鉛直変位であり, · は時間に関する微 分を示す。

浮屋根面に働く動液圧 $p$ は，線形化されたベルヌーイ式に より

$$
p=-\rho\left(\frac{\partial \phi}{\partial t}\right)_{z=H}-\rho g u
$$

でケえられる。ここに， $\rho$ は流体密度， $g$ は重力加速度である。 また浮屋根の速動方程式は，減非を無視すれば，次式で表さ れる。

$$
D \nabla^{4} w+m \ddot{w}=p
$$

\section{2 浮屋根変位の固有モ一ド展開}

浮后根および液面门連動の振帆は微小で線形厅は合わせが成り

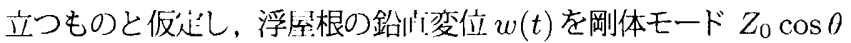

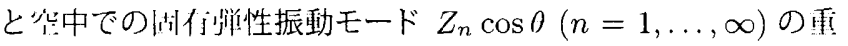
ね合わせによって，次式のように表现する。

$$
w(t)=\sum_{n=0}^{\infty} \xi_{n}(t) Z_{n} \cos \theta
$$

ここに

$$
Z_{0}=\frac{r}{R}, \quad Z_{n}=\alpha_{n} J_{1}\left(k_{n} \frac{r}{R}\right)+\beta_{n} I_{1}\left(k_{n} \frac{r}{R}\right)
$$

で, $J_{1}$ は 1 次の第 1 䅦ベッセル関数を， $I_{1}$ は 1 次の第 1 種変 形ベッセル関数を示す。また $k_{n}$ は波数であり，浮忤根の呪中に おける $n$ 次固们円振動数 $\omega_{n}$ と次式によって関係づけられる。

$$
k_{n}^{4}=\frac{m R^{4}}{D} \omega_{n}^{2}
$$

$k_{n}$ および $\alpha_{n}$ と $\beta_{n}$ の振幅比は自由端条件から熟かれる次の 「汀次方和式が非|明解を付する条件より定められる。

$$
\left[\begin{array}{ll}
c_{11} & c_{12} \\
c_{21} & c_{22}
\end{array}\right]\left\{\begin{array}{c}
\alpha_{n} \\
\beta_{n}
\end{array}\right\}=\left\{\begin{array}{l}
0 \\
0
\end{array}\right\}
$$

ここに

$$
\begin{aligned}
c_{11}= & k_{n}^{2} J_{1}^{\prime \prime}\left(k_{n}\right)+\nu k_{n} J_{1}^{\prime}\left(k_{n}\right)-\nu J_{1}\left(k_{n}\right) \\
c_{12}= & k_{n}^{2} I_{1}^{\prime \prime}\left(k_{n}\right)+\nu k_{n} I_{1}^{\prime}\left(k_{n}\right)-\nu I_{1}\left(k_{n}\right) \\
c_{21}= & k_{n}^{3} J_{1}^{\prime \prime \prime}\left(k_{n}\right)+k_{n}^{2} J_{1}^{\prime \prime}\left(k_{n}\right)-k_{n}(3-\nu) J_{1}^{\prime}\left(k_{n}\right) \\
& \quad+(3-\nu) J_{1}\left(k_{n}\right) \\
c_{22}= & k_{n}^{3} I_{1}^{\prime \prime \prime}\left(k_{n}\right)+k_{n}^{2} I_{1}^{\prime \prime}\left(k_{n}\right)-k_{n}(3-\nu) I_{1}^{\prime}\left(k_{n}\right) \\
& +(3-\nu) I_{1}\left(k_{n}\right)
\end{aligned}
$$

で, はポアソン比である。

\section{3 速度ポテンシャルの解表現}

連続方程式 (1a), 側壁条件 (1b) および底面条件 (1c) を満た す速度ポテンシャル $\phi$ の解は次式で与えられる。

$$
\phi=\left[\dot{x}_{g}(t) r+\sum_{i=1}^{\infty} A_{i}(t) \cosh \left(\epsilon_{i} \frac{z}{R}\right) J_{1}\left(\epsilon_{i} \frac{r}{R}\right)\right] \cos \theta
$$


ここに, $\epsilon_{i}$ は $J_{1}^{\prime}\left(\epsilon_{i}\right)=0$ の正の実根である。

(4), (9)を (1d)に代入すれば, 液面の運動学的条件は

$$
\sum_{i=1}^{\infty} A_{i}(t) \frac{\Omega_{i}^{2}}{g} \cosh \left(\epsilon_{i} \frac{H}{R}\right) J_{1}\left(\epsilon_{i} \frac{r}{R}\right)=\sum_{n=0}^{\infty} \dot{\xi}_{n}(t) Z_{n}
$$

と表される。ここに， $\Omega_{i}$ は次式で与えられる自由液面の $i$ 次の スロッシング胡们円振動数である。

$$
\Omega_{i}=\sqrt{\frac{g}{R} c_{i} \tanh \left(\epsilon_{i} \frac{H}{R}\right)}
$$

(10) の両辺に $(r / R) J_{1}\left(\epsilon_{i} r / R\right)$ を掛け $0 \leq r / R=u \leq 1$ に わたって積分し，付録のベッセル関数の直交関係 $(\mathrm{A} 1)$ を利用 すれば，末定関数 $A_{i}$ に対して

$$
A_{i}(t)=\frac{2}{\epsilon_{i}^{2}-1} \frac{1}{\cosh \left(\epsilon_{i} \frac{H}{R}\right)} \frac{1}{J_{1}\left(\epsilon_{i}\right)} \frac{g}{\Omega_{i}^{2}} \sum_{n=0}^{\infty} a_{i n} \dot{\xi}_{n}(t)
$$

を得る。ここに

$$
a_{\text {in }}=\frac{\epsilon_{i}^{2}}{J_{1}\left(\epsilon_{i}\right)} \int_{0}^{1} u Z_{n} J_{1}\left(c_{i} u\right) d u
$$

であり，(5)を代入し積分公式 (A2)〜 (A4) を用いれば

$$
\begin{aligned}
& a_{i 0}=1 \\
& a_{i n}=\epsilon_{i}^{2} k_{n}\left[\frac{\alpha_{n}}{\epsilon_{i}^{2}-k_{n}^{2}} J_{1}^{\prime}\left(k_{n}\right)+\frac{\beta_{n}}{\epsilon_{i}^{2}+k_{n}^{2}} I_{1}^{\prime}\left(k_{n}\right)\right] \quad(n \geq 1)
\end{aligned}
$$

となる。

(12)を (9)に代入すれば，速度ポテンシャルの解は

$$
\begin{aligned}
\phi= & {\left[\dot{x}_{g}(t) r+\sum_{i=1}^{\infty} \frac{2}{\epsilon_{i}^{2}-1} \frac{g}{\Omega_{i}^{2}} \frac{\cosh \left(\epsilon_{i} \frac{z}{R}\right)}{\cosh \left(\epsilon_{i} \frac{H}{R}\right)} \frac{J_{1}\left(\epsilon_{i} \frac{r}{R}\right)}{J_{1}\left(\epsilon_{i}\right)}\right.} \\
& \left.\cdot \sum_{n=0}^{\infty} a_{i n} \dot{\xi}_{n}(t)\right] \cos \theta
\end{aligned}
$$

と表される。

\section{4 運動方程式の解}

(2)に (4)，(14)を代入すれば，浮屋根面に作用する動液圧は

$$
\begin{aligned}
p=- & \rho\left[\ddot{x}_{g}(t) r+\sum_{i=1}^{\infty} \frac{2}{\epsilon_{i}^{2}-1} \frac{g}{\Omega_{i}^{2}} \frac{J_{1}\left(\epsilon_{i} \frac{r}{R}\right)}{J_{1}\left(\epsilon_{i}\right)} \sum_{n=0}^{\infty} a_{i n} \ddot{\xi}_{n}(t)\right. \\
& \left.+g \sum_{n=0}^{\infty} Z_{n} \xi_{n}(t)\right] \cos \theta
\end{aligned}
$$

で与えられる。

（3）に (4)，(15)を代入すれば, 浮屋根の運動方程式は

$$
\begin{aligned}
\sum_{n=0}^{\infty} m\left[\ddot{\xi}_{n}(t)+\omega_{n}^{2} \xi_{n}(t)\right] Z_{n} \\
=-\rho\left[\ddot{x}_{g}(t) r+\sum_{i=1}^{\infty} \frac{2}{\epsilon_{i}^{2}-1} \frac{g}{\Omega_{i}^{2}} \frac{J_{1}\left(\epsilon_{i} \frac{r}{R}\right)}{J_{1}\left(\epsilon_{i}\right)} \sum_{n=0}^{\infty} a_{i n} \ddot{\xi}_{n}(t)\right. \\
\left.\quad+g \sum_{n=0}^{\infty} Z_{n} \xi_{n}(t)\right]
\end{aligned}
$$

と畫き表される。

(16) の両辺に $(r / R) Z_{n}$ を掛け $0 \leq r / R=u \leq 1$ にわたって 積分し,さらにモードの直交性を利用して整理すれば

$$
\sum_{l=0}^{\infty}\left(\delta_{n l}+\mu_{n l}\right) \ddot{\xi}_{l}(t)+\left(\omega_{n}^{2}+\frac{\rho g}{m}\right) \xi_{n}(t)=-\gamma_{n} \ddot{x}_{g}(t)
$$

を得る。ここに， $\delta_{n l}$ はクロネッカ記号を示し，

$$
\begin{aligned}
& \mu_{n l}=\frac{\rho}{m \Delta_{n}} \sum_{i=1}^{\infty}\left[\frac{2}{c_{i}^{2}-1} \frac{g}{\Omega_{i}^{2}} \frac{1}{J_{1}\left(\epsilon_{i}\right)} a_{i l} \int_{0}^{1} u Z_{n} J_{1}\left(\epsilon_{i} u\right) d u\right] \\
& \gamma_{n}=\frac{\rho R}{m \Delta_{n}} \int_{0}^{1} u^{2} Z_{n} d u, \quad \Delta_{n}=\int_{0}^{1} u Z_{n}^{2} d u
\end{aligned}
$$

である。上式に (5)，(13) を代入しベッセル関数の積分公式 9) を用いれば， $\Delta_{n} ， \mu_{n l}, \gamma_{n}$ はそれぞれ次のように表される。

$$
\begin{aligned}
\Delta_{0}= & \frac{1}{4} \\
\Delta_{n}= & \frac{1}{2} \alpha_{n}^{2}\left[\left\{J_{1}\left(k_{n}\right)\right\}^{2}-J_{0}\left(k_{n}\right) J_{2}\left(k_{n}\right)\right] \\
& \quad+\frac{\alpha_{n} \beta_{n}}{k_{n}}\left[J_{1}\left(k_{n}\right) I_{2}\left(k_{n}\right)+J_{2}\left(k_{n}\right) I_{1}\left(k_{n}\right)\right] \\
& +\frac{1}{2} \beta_{n}^{2}\left[\left\{I_{1}\left(k_{n}\right)\right\}^{2}-I_{0}\left(k_{n}\right) I_{2}\left(k_{n}\right)\right] \quad(n \geq 1) \\
\mu_{n l}= & \frac{\rho}{m} \sum_{i=1}^{\infty}\left[\frac{2}{\epsilon_{i}^{2}\left(c_{i}^{2}-1\right)} \frac{g}{\Omega_{i}^{2}} \frac{a_{i n} a_{i l}}{\Delta_{n}}\right] \\
\gamma_{0}= & \frac{\rho R}{m} \\
\gamma_{n}= & \frac{\rho R}{m} \frac{\alpha_{n} J_{2}\left(k_{n}\right)+\beta_{n} I_{2}\left(k_{n}\right)}{k_{n} \Delta_{n}} \quad(n \geq 1)
\end{aligned}
$$

連動方程式 (17)において，左辺の $\mu_{n l}$ は液体の付加質量を, $\rho g / m$ は浮力変化に伴う復元力をそれぞれ $m$ で除したものに対 応している。ここでは, 空中の固有振動モードを用いて艮開し ているため, 通学のモード分解法のようにモードごとに独立し た式にはならない。液体中の固有振動特性は (17) の右辺を 0 と おいた自由振動方程式を解くことによって得られる。

（17）は非減衰の連動方程式であるが, 適当な減衰（剛性比例 型減衰あるいはレーリー型減衰など）を考慮してこれを解けば， モード変位 $\xi(t)$ が得られる。

\section{5 解の最終表示}

モ一ド変位 $\xi(t)$ が得られれば, これを (4), (14) および $(15)$ に代入することによって浮屋根変位 $w$, 速度ポテンシャル $\phi$ お よび動液圧 $p$ の解が得られる。

キルヒホッフの平板理論によれば, 浮屋根面の曲率とねじり 率は

$$
\begin{aligned}
\kappa_{r} & =\frac{\partial^{2} w}{\partial r^{2}}, \quad \kappa_{\theta}=\frac{1}{r} \frac{\partial w}{\partial r}+\frac{1}{r^{2}} \frac{\partial^{2} w}{\partial \theta^{2}} \\
\kappa_{r \theta} & =\frac{1}{r} \frac{\partial^{2} w}{\partial r \partial \theta}-\frac{1}{r^{2}} \frac{\partial w}{\partial \theta}
\end{aligned}
$$

で与えられる。(21)に (4)，(5)を代入すれば

$$
\kappa_{r}=\sum_{n=1}^{\infty} \xi_{n}(t)\left(\frac{k_{n}}{R}\right)^{2}\left[\alpha_{n} J_{1}^{\prime \prime}\left(k_{n} \frac{r}{R}\right)+\beta_{n} I_{1}^{\prime \prime}\left(k_{n} \frac{r}{R}\right)\right]
$$




$$
\begin{aligned}
\kappa_{\theta}= & \sum_{n=1}^{\infty} \xi_{n}(t) \frac{k_{n}}{R r}\left[-\alpha_{n} J_{2}\left(k_{n} \frac{r}{R}\right)+\beta_{n} I_{2}\left(k_{n} \frac{r}{R}\right)\right] \\
\kappa_{r \theta}= & \sum_{n=1}^{\infty} \cos \theta \\
\cdot \sin \theta & \xi_{n}(t) \frac{k_{n}}{R r}\left[\alpha_{n} J_{2}\left(k_{n} \frac{r}{R}\right)-\beta_{n} I_{2}\left(k_{n} \frac{r}{R}\right)\right]
\end{aligned}
$$

が得られ，曲げモーメントとねじりモーメントは

$$
\begin{aligned}
M_{r} & =-D\left(\kappa_{r}+\nu \kappa_{\theta}\right), \quad M_{\theta}=-D\left(\kappa_{\theta}+\nu \kappa_{r}\right) \\
M_{r \theta} & =-D(1-\nu) \kappa_{r \theta}
\end{aligned}
$$

により算定される。

\section{3. 解析例および考察}

\section{1 解析モデル}

解析例として用いたモデル泞榑の㵔元を表 1 に示す。これら は実機 10 万 $\mathrm{kl}$ タンクの，渚元を参考に没迟したモデルであり， 浮屋根の形式, 曲げ剛性と所接のみを変化させ，その他のパラ メータは一定としている。ここでは便门上，ダブルデッキ形式 の浮庄根を模した図 2(a)のような断i面構成のものを D モデル, シングルデッキ形式の浮ケ!根を模した図 (b) のような断伯揹成 （注 1）のものを S モデルと総称し, 各モデルを浮な!根の曲げ剛 性と質㻎の值によって表 2 に示すようなモデル記っを䏘いて 別する。曲げ剛性の算定は下式による。

- D モデル

$$
D=\frac{E\left[d^{3}-\left(d-2 t_{e}\right)^{3}\right]}{12\left(1-\nu^{2}\right)}
$$

- S モデル

$$
D=\frac{E t_{e}^{3}}{12\left(1-\nu^{2}\right)}
$$

表 1: モデル貯槽の新元

\begin{tabular}{|c|c|c|}
\hline モデル & $\mathrm{D}$ モデル & $\mathrm{S}$ モデル \\
\hline \hline 浮屋根形式 & ダブルデッキ & シングルデッキ \\
\hline 貯槽半径 $R$ & $40 \mathrm{~m}$ & $40 \mathrm{~m}$ \\
\hline 液体深さ $H$ & $20 \mathrm{~m}$ & $20 \mathrm{~m}$ \\
\hline 液体密度 $\rho$ & $0.85 \mathrm{t} / \mathrm{m}^{3}$ & $0.85 \mathrm{t} / \mathrm{m}^{3}$ \\
\hline 浮屋根曲げ剛性 & & \\
$D /\left(\rho g R^{4}\right)$ & $0.005,0.01$ & $10^{-7}$ \\
\hline 浮屋根質量 & & \\
$m /(\rho R)$ & $0.01,0.02$ & $0.01,0.02$ \\
\hline 減衰定数 & & \\
浮屋根なし & $0.1 \%$ & $0.1 \%$ \\
浮屋根あり & $1.0 \%$ & $0.5 \%$ \\
\hline 採用モード数 & & 24 \\
スロッシング & 7 & 25 \\
ス浮屋根応答 & 6 & \\
\hline \multicolumn{2}{|c|}{} \\
\hline
\end{tabular}

表 2: モデル記号一覧

\begin{tabular}{|c|c|c|}
\hline$D /\left(\rho g R^{4}\right)$ & $m /(\rho R)=0.01$ & $m /(\rho R)=0.02$ \\
\hline \hline 0.01 & D1L & D1H \\
\hline 0.005 & D2L & D2H \\
\hline $10^{-7}$ & SL & SH \\
\hline
\end{tabular}

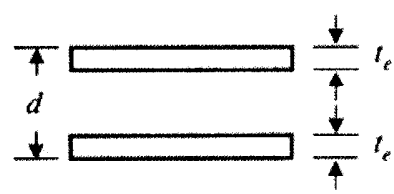

(a) D そデル

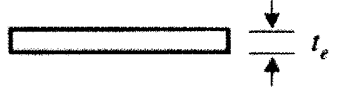

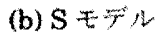

図 2: 浮屋根の断面構成

ここに，dは浮屋根総原， $t_{e}$ は有効りム厚を示す（図 2 )。

\section{2 固有振動解析}

自由振動方程式の固份值解析により得られた各モデルの固有 周期（液体中）を図 3 に示す。1 次固有周期はモデルによらず ほぼ一定で，自由液面の 1 次固有周期とほぼ一致する。D モデ

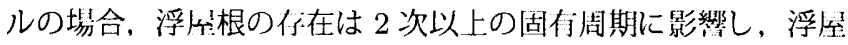
根の剛性が㙏加するほど阁住拮期は短くなるが， $\mathrm{S}$ モデルでは

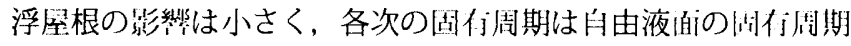
よりもわずかに长くなる程度である。浮厔根の所旨が液体の付

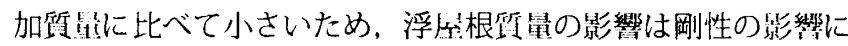
比べると小さい。これらの佔向はいずれも坂井ら ${ }^{6)}$ の研究絬果 と符合している（注 2)。

\section{3 地震応答解析}

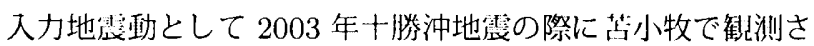
れた地震波（K-NET 公閉波 HKD1290309260450EW）を採川 し，時刻歴応答解析を行った。时刻磨応答解析には地継繶时 III 300s に対して时间阳㜔を 0.01s としてニューマークの $\beta$ 法 （ $\beta=1 / 4 ）$ を採肜た。また減哀は剛性比例型とし，1 次モ一 ド（液体中）に対して表 1 に示す減衰定数を扴いた。

入力地動加速度, 液消（居根消）変位, 浮座根面動液圧およ び半径方向曲げモーメントの时刻梵波形と対応するフーリエ振 艧スペクトルを D1L モデルについて図 4，5に示す。

本解析例の場合，由由液面のスロッシング固佮周期は 1 次が $10.97 \mathrm{~s}, 2$ 次が $5.52 \mathrm{~s}$ に対して, D1L モデルの浮庄根の间住礼 期は 1 次が $11.00 \mathrm{~s}, 2$ 次が $2.49 \mathrm{~s}$ である。液面変位では浮至根 の有無にかかわらず 1 次モード成分が卓越しているが, 自由液 面の場合は 2 次モードの影的も無視できない。一方, 浮屋根面 の動液圧や曲げモーメントでは, 1 次モードに加え 2 次モード

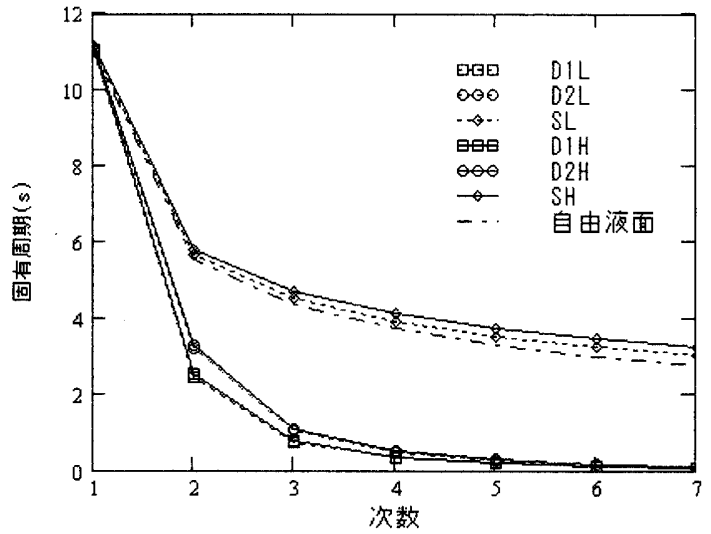

図 3: 各モデルの固有周期 

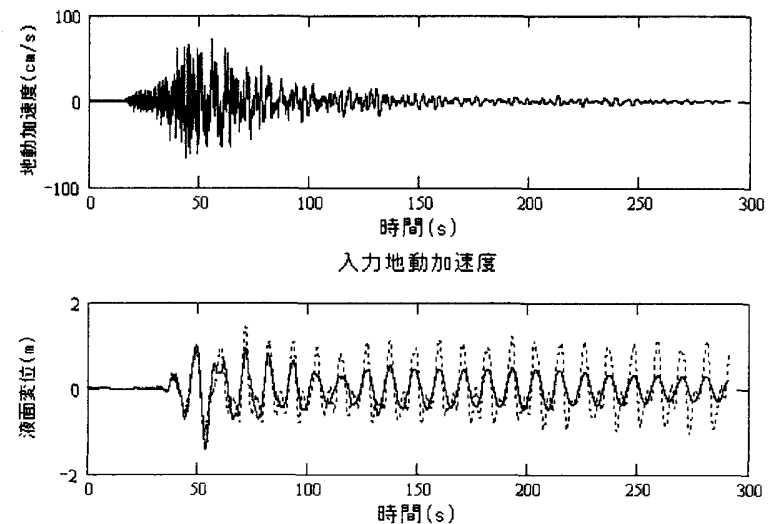

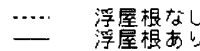

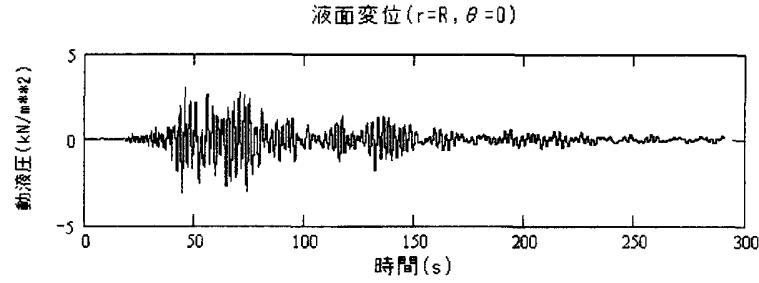

動液圧 $(r=0.4 R, \theta=0)$

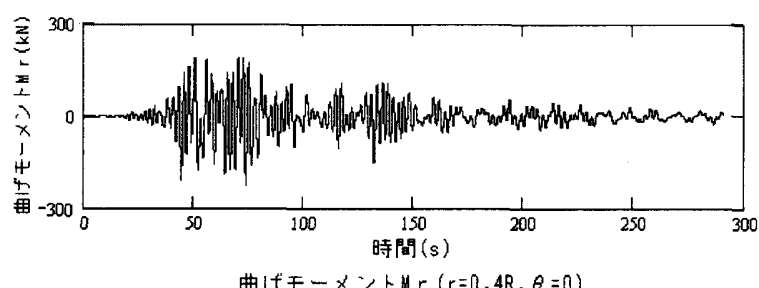

図 4: 入力加速度と応答の時刻歴波形（D1L モデル）
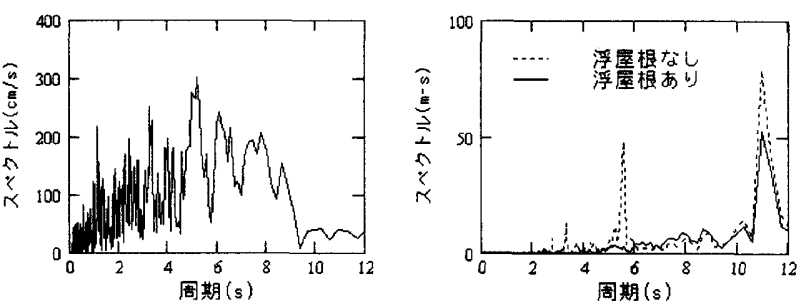

入力地動加速度

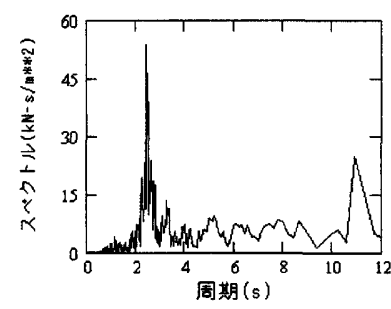

動源压 $(r=0.4 R, \theta=0)$

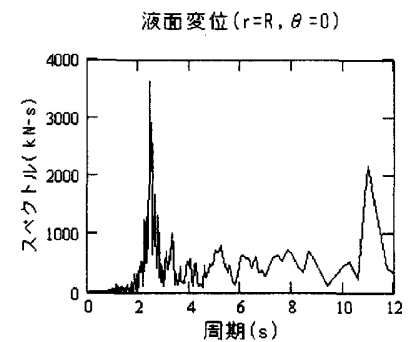

曲げモーメントMr $(r=0.4 R, \theta=0)$

図 5: 入力加速度と応答のフーリエ振幅スペクトル （D1L モデル）

成分の寄与が顕著である。時刻歷波形を見ると，液面変位は地 震動の主要動が去った後も減衰せず, 1 次モード主体の振動を 長時間継続しているのに対して, 動液圧や曲げモーメントは地 震動の主要動が作用している間は主として 2 次モードで振動し， 主要動が去った後は液面変位と同周期の 1 次モードの振動だけ が残り, 最大振幅は 2 次モードが卓越している地震動の主要動

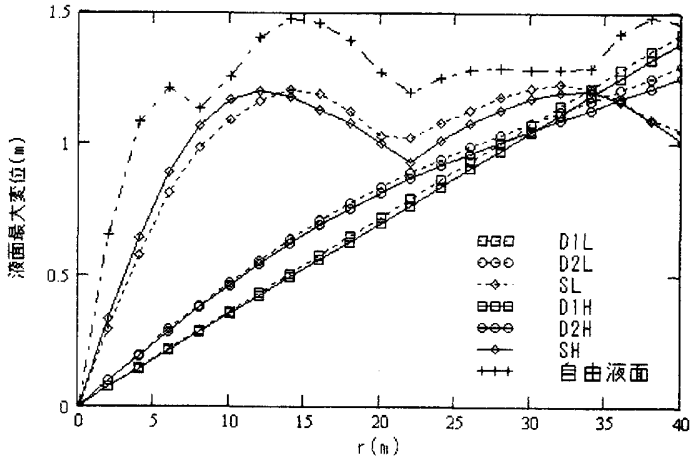

液面最大变位

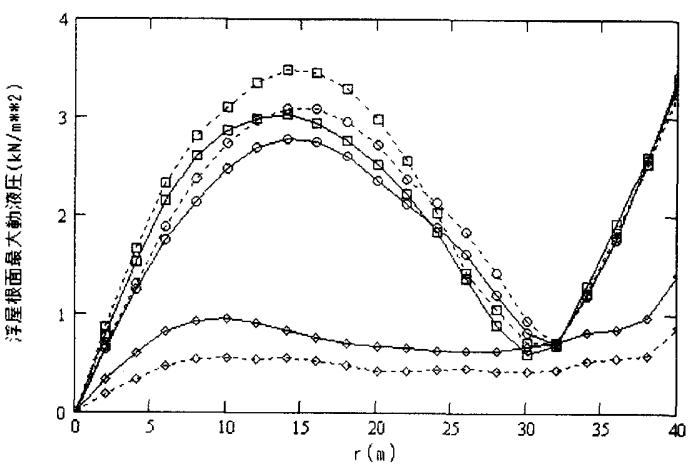

浮屋根面最大動液圧

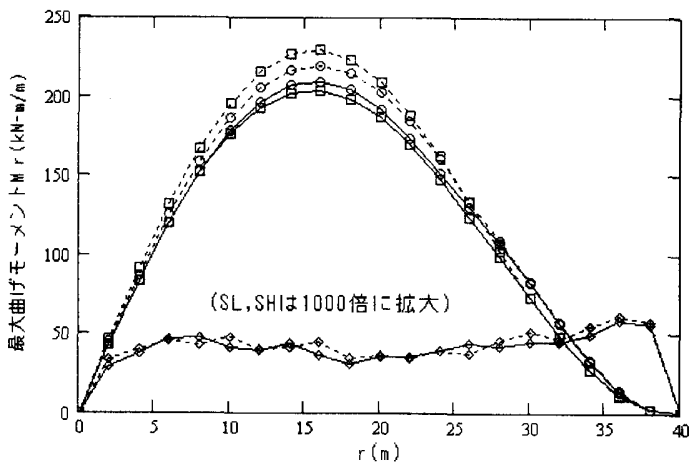

浮屋根最大曲げモーメンドr

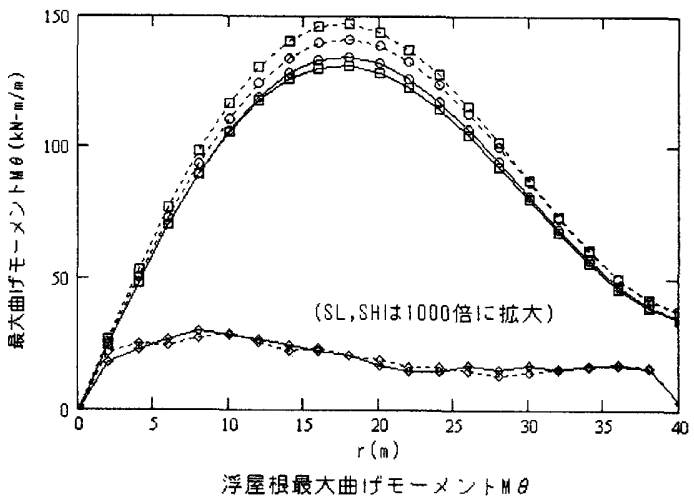

図 6: 各モデルの最大応答值の空間分布 $(\theta=0)$

が作用している間に生じている。

各モデルの液面変位, 浮屋根面動液圧および曲げモーメント の最大応答值の $\theta=0$ に沿う分布を比較して図 6 に示す。

D モデルの場合, 剛性の高い D1L モデル，D1H モデルで は浮屋根はほぼ剛体的に変位しているが，それょり剛性の低い D2L モデル，D2H モデルでは弹性変形の影響が現れ，剛性の 
低下とともに自由液面の変位に少しずつ近づいて行く傾向が見 られる。浮屋根による拘束効果により貯槽内部の変位は自由液 面の変位よりもかなり小さくなるが, 側壁における変位は自由 液面の場合と大差ない。一方, S モデルの場合は, 浮屋根によ る拘束効果はきわめて小さく, SL モデル，SH モデルともに白 由液面変位に近い最大変位分布となっている。

動液圧は浮屋根剛性が高くなるほど大きくなり, 曲げモーメ ントも剛性が高くなるほど增加する傾向を示す。動液圧は, D モデルの場合, $r=0.4 R$ 付近で鼠大となり, その後 $r$ の増加と ともに減少して $r=0.8 R$ 付近で正負を反転して端部 $r=R$ ま で単調増加する分布性状を示すが（図 6 は各点の最大応答の絶 対值を示しているので, 各時刻の瞬間的な応答分布性状はこの 図からは読み取れない），S モデルでは埸所による差は殆ど見 られない。曲げモーメントも，D モデルでは $r=0.4 R$ 付近で 最大傎をとるが，S モデルでは場所による到は殆ど見られない。 全体的に半径方向曲げモーメント $M_{r}$ の方が㑑方向曲げモーメ ント $M_{\theta}$ よりも大きく, $M_{r}$ は $M_{\theta}$ の約 1.5 价になっている。

浮屋根質量の影樂について兄ると, D モデルでは浮质根の所 量が小さいほど動液圧や曲げモーメントが增加し， $\mathrm{S}$ モデルで は逆に動液圧が減少し，曲げモーメントは殆ど変わらないが， その影響は剛性の影㲧に比べると小さい。

\section{4 断面算定例}

以上の結果から分かるように，浮座根の断拆を決足する主紧 な応力は半径方向曲げモーメント $M_{r}$ による曲げ応力である。

例として，D1L モデルについて検封して少ると, 図 6 より坟 大曲げモーメントは $\left.M_{r}\right|_{\text {max }}=229 \mathrm{kN}-\mathrm{m} / \mathrm{m}$ である。曲げ剛性 は $D /\left(\rho g R^{4}\right)=0.01$ であるから，総厚を $d=80 \mathrm{~cm}$ と仮这すると (24) より有効りム㫗は $t_{e}=0.297 \mathrm{~cm}$ となる。圧縮側の付効りム 厚は座屈を考慮して $t_{e} / 3$ に減ずると仮定し洋位幅当たりの断 面係数を算定すると $Z \cong t_{e} d / 3=7.92 \mathrm{~cm}^{2}$ となり, 曲げ応力脑 は $\sigma_{r}=229 / 7.92=28.9 \mathrm{kN} / \mathrm{cm}^{2}$ となって，銅材の降伏応力度と 比較しうる值となる。

一方, SL モデルについて検討すると, $\left.M_{r}\right|_{\max }=0.0611 \mathrm{kN}-$ $\mathrm{m} / \mathrm{m}$, また $D /\left(\rho g R^{4}\right)=10^{-7}$ であるから，(25) より $t_{e}=0.484 \mathrm{~cm}, Z=t_{e}^{2} / 6=0.039 \mathrm{~cm}^{2}$ となり, 曲げ応力度は $\sigma_{r}=0.0611 / 0.039=1.57 \mathrm{kN} / \mathrm{cm}^{2}$ となって, 鋼材の降伏応力度 よりも一桁小さい值となる。

以上をまとめると, ダブルデッキ形式の浮屋根においては， 半径方向曲げモーメントによる曲げ応力が断面設計を決定する 主要な応力となる。一方, シングルデッキ形式の浮屋根の場合 は, 曲げ応力度は鋼材の降伏応力度に比べて十分小さく，むし ろ大変形効果による膜応力（線形理論では考慮できない）が支 配的になると予想される。

\section{4. 結語}

一様な剛性・質量分布の浮屋根を有する剛な平底円筒液体貯 槽を対象に, 地震時スロッシング応答の解析解を線形ポテンシャ ル理論に基づいて導出した。さらに，適用例として実機 10 万 $\mathrm{kl}$ タンク相当のモデルに対する解析結果を示し, 浮屋根の形式, 剛性や質量がスロッシング応答に及ぼす影響を検討した。浮屋
根応力を検钨した結果, ダブルデッキ形式の浮屋根においては, 半径方向曲げモーメントによる曲げ応力が断面設計を決定する 主要な応力となること, 一方, シングルデッキ形式の浮㸝根に おいては, 曲げ応力度は降伏応力度に比べて十小さく, むしろ 大変形効果による膜応力が支配的になる可能性があることを指 摘した。

導出された解はベッセル関数を含む陽な関数形で表示されて おり，スロッシング基本性状のパラメトリックな把握や初期設 尌段階での予備的な検讨に役立つものと考える。今後, 半径方 向と阔方向とで剛性が晎なる直交異方性のダブルデッキ形式浮 屋根や外梨ポンツーンを有するシングルデッキ形式浮屋根のよ うなより笑際的な場合についても解を導出し，稿を改めて報告 する予企である。

\section{謝辞}

本研究には平成 16 年位名城大学総合研究所学術研究奨/动助

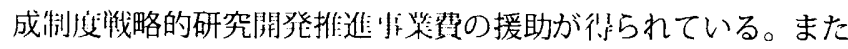

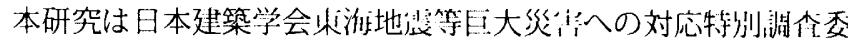

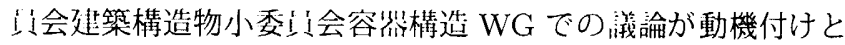

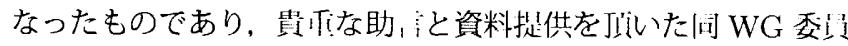
各位に謝意を表する。なお，地震波には独立行政法人防災科”学 技術研究所の強震観测網 K-NET 公開波を使川儿た。

注

1.ここでは一様な厚さの平板によってシングルデッキ形式の浮屋根を モデル化しており，外琺にポンッーンを们するや際のシングルデッ キ形式浮展根とは必ずしも対応していないことに注意されたい。

2. 坂井ら 6) はダブルデッキ形式浮屋根の下板の局部変形を考虑した

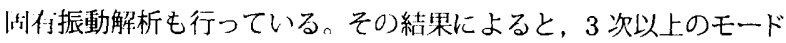
では下板の川部変形の影嬵が無視できず，㞹们周期は本解析例の ように一枚板と仮定した塌合よりもかなり这くなるが，2次までの モードにはその晾嵒は现れない。

\section{参考文献}

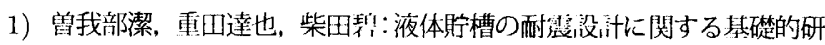
究, 東京大学生産技術研究所報管, 第 26 卷, 第 7 号, pp.261-290, 1977.3

2) K. Senda and K. Nakagawa: On the Vibration of an Elevated Water Tank - I, II, Technical Report of Osaka University, No.117, 1954, No.170, 1955

3) 日本建築学会 : 容器構造設計指針・同解説, 1996

4）坂井藤一：2003 年十勝沖地震における浮屋根式タンクの被害につ いて, JSSC, No.52, pp.20-25, 2004.4

5) 山本善之：地震による石油タンクの液面の動摇と衝撃圧, 高圧力, 第 3 巻, 第 1 号, pp.2-8, 1965.1

6) Sakai, F., Nishimura, M. and Ogawa, H.: Sloshing Behavior of Floating-Roof Oil Storage Tanks, Computers and Structures, Vol.19, No.1-2, pp.183-192, 1984

7）池田澄人, 藤波昌, 酒井守雄, 愛屋憲一, 坂井藤一, 西村正弘： 半地下式石油備蓄タンクの設計について, 川崎重工技報, 76 号, pp.59-66, 1980.10 
8）西口英夫, 伊藤雅文, 保延宏行, 加納俊哉：長周期地震動による 大容量石油タンクのスロッシング挙動解析と安全性評価, 火力原 子力協会誌, Vol.56, No. 581, 2005.2

9）森口繁一, 守田川銈久, 一松信: 数学公式 3 -特殊関数一, 岩波 書店, 1960

10）犬井鉄郎：偏微分方程式とその応用, コロナ社, 1957

\section{付録：積分公式}

$\epsilon_{i}$ を $J_{1}^{\prime}\left(\epsilon_{i}\right)=0$ の正の実根とすると, 次のような直交関係が成り 立つ〔文献 10), 式 (8.60), p.168 参照〕。

$$
\int_{0}^{1} u J_{1}\left(\epsilon_{i} u\right) J_{1}\left(\epsilon_{j} u\right) d u= \begin{cases}\frac{1}{2}\left(1-\frac{1}{\epsilon_{i}^{2}}\right)\left[J_{1}\left(\epsilon_{i}\right)\right]^{2} & i=j \\ 0 & i \neq j\end{cases}
$$

$$
\begin{aligned}
& \text { ベッセル関数の積分公式 9) より } \\
& \int_{0}^{1} u^{2} J_{1}\left(\epsilon_{i} u\right) d u=\frac{1}{\epsilon_{i}} J_{2}\left(\epsilon_{i}\right)=\frac{1}{\epsilon_{i}^{2}} J_{1}\left(\epsilon_{i}\right)-\frac{1}{\epsilon_{i}} J_{1}^{\prime}\left(\epsilon_{i}\right)
\end{aligned}
$$

$$
\begin{aligned}
& \int_{0}^{1} u J_{1}\left(k_{n} u\right) J_{1}\left(\epsilon_{i} u\right) d u=\frac{k_{n} J_{0}\left(k_{n}\right) J_{1}\left(\epsilon_{i}\right)-\epsilon_{i} J_{1}\left(k_{n}\right) J_{0}\left(\epsilon_{i}\right)}{\epsilon_{i}^{2}-k_{n}^{2}} \\
& \int_{0}^{1} u I_{1}\left(k_{n} u\right) J_{1}\left(\epsilon_{i} u\right) d u=\frac{k_{n} I_{0}\left(k_{n}\right) J_{1}\left(\epsilon_{i}\right)-\epsilon_{i} I_{1}\left(k_{n}\right) J_{0}\left(\epsilon_{i}\right)}{\epsilon_{i}^{2}+k_{n}^{2}}
\end{aligned}
$$

上式に $J_{1}^{\prime}\left(\epsilon_{i}\right)=J_{0}\left(\epsilon_{i}\right)-J_{1}\left(\epsilon_{i}\right) / \epsilon_{i}=0$, i.e., $J_{0}\left(\epsilon_{i}\right)=J_{1}\left(\epsilon_{i}\right) / \epsilon_{i}$ の 関係を用いれば，次式を得る。

$$
\begin{aligned}
\int_{0}^{1} u^{2} J_{1}\left(\epsilon_{i} u\right) d u=\frac{1}{\epsilon_{i}^{2}} J_{1}\left(\epsilon_{i}\right) & \\
\int_{0}^{1} u J_{1}\left(k_{n} u\right) J_{1}\left(\epsilon_{i} u\right) d u & =\frac{\left[k_{n} J_{0}\left(k_{n}\right)-J_{1}\left(k_{n}\right)\right] J_{1}\left(\epsilon_{i}\right)}{\epsilon_{i}^{2}-k_{n}^{2}} \\
& =\frac{k_{n}}{\epsilon_{i}^{2}-k_{n}^{2}} J_{1}^{\prime}\left(k_{n}\right) J_{1}\left(\epsilon_{i}\right) \\
\int_{0}^{1} u I_{1}\left(k_{n} u\right) J_{1}\left(\epsilon_{i} u\right) d u & =\frac{\left[k_{n} I_{0}\left(k_{n}\right)-I_{1}\left(k_{n}\right)\right] J_{1}\left(\epsilon_{i}\right)}{\epsilon_{i}^{2}+k_{n}^{2}} \\
& =\frac{k_{n}}{\epsilon_{i}^{2}+k_{n}^{2}} I_{1}^{\prime}\left(k_{n}\right) J_{1}\left(\epsilon_{i}\right)
\end{aligned}
$$

